\title{
Challenging glass in challenging times
}

\author{
Jan Belis 10 - Christian Louter 1 \\ Jens Henrik Nielsen $(\mathbb{D}$ - Jens Schneider $(\mathbb{D}$. \\ Mauro Overend (i)
}

Published online: 30 September 2020

(C) Springer Nature Switzerland AG 2020

Hardly any event in recent history has put such a tremendous pressure on society worldwide as COVID19. As also today the way we live and work is still highly affected by it, our thoughts are with those who have experienced the awful effects of the Corona-virus up close.

Whilst the economic effects on construction in general and the glass sector in particular may only become fully visible in the months ahead of us, glass itself has played and is playing a very important role these days. Thanks to the transparency of glass, elderly and other people in the risk zone could still see visitors without

\section{J. Belis $(\varangle)$}

Department of Structural Engineering and Building

Materials, Ghent University, Ghent, Belgium

e-mail: jan.belis@ugent.be

\section{Louter}

Institute of Building Construction, Technische Universität Dresden, Dresden, Germany

e-mail: christian.louter@tu-dresden.de

\section{J. H. Nielsen}

Department of Civil Engineering, Technical University of Denmark, Kgs. Lyngby, Denmark

e-mail: jhn@byg.dtu.dk

\section{J. Schneider}

Institute of Structural Mechanics and Design, Technische

Universität Darmstadt, Darmstadt, Germany

e-mail: schneider@ismd.tu-darmstadt.de

\section{Overend}

Faculty of Architecture and the Built Environment, Delft University of Technology, Delft, The Netherlands

e-mail: m.overend@tudelft.nl physically compromising their own health. In spite of lockdowns and travel restrictions, millions of people could remain in touch through online communication, drawing energy from human connections made through the glass of their displays. Let this be an encouragement for all of us to keep pushing the limits of this material so that society can benefit from it to the utmost.

Now, what challenging topics does the current Challenging Glass special issue bring us?

Starting with a hardcore structural topic, Nielsen et al. present a novel concept for reinforced laminated glass beams carrying long term loads, combining annealed and thermally toughened glass and accounting for relaxation of the interlayer. Next, Kraus and Drass explore new grounds with their paper on the potential of artificial intelligence applied to structural glass engineering applications. We believe this subject will certainly gain importance in engineering in general but also in our field.

The next set of papers deal with insulated glass units (IGU). More specifically, Bott reveals the main engineering challenges and solutions of slumped IGU's with large airspaces, whereas Bedon and Amadio concentrate on IGU's with silicone sealed spacer connections using an experimental and numerical approach, respectively.

More silicone-related insights are provided by Drass and Kraus, who discuss a Eurocode-compliant, meshindependent numerical approach for dimensioning silicone adhesive joints. 
From silicones it is only a small step to adhesion, the topic of contributions by Schuster et al. and Fourton et al. Where the former assess the Pummel test, the latter investigates adhesion failure in laminated glass using through-cracked tensile tests.

The last three contributions have in common that they relate to the strength of glass, be it from different perspectives. The first one by Bukieda et al. studies the optical quality and strength of glass edges after the grinding and polishing process. The second contribution is a brief report by Schwind et al., focusing at double ring bending tests on heat pre-treated soda lime silica glass. The third paper is by Bristogianni et al. and reports about their findings with respect to the flexural strength of recycled cast glass.

Last but not least, we would like to firmly congratulate Dr Andreas Kasper for winning the Glass Structures \& Engineering 2019 best paper award. The prize was handed out for the very first time, during an online ceremony on September $4^{\text {th }}, 2020$, which was witnessed by about 300 attendees from the architectural and structural glass community worldwide. The winning paper is the third part in a series of four on nickel sulphide inclusions in glass, which as a whole we believe will become an exceptional reference work on this topic (Kasper 2019a, b; Kasper et al. 2019; Kasper and Rubbert 2020).

Enjoy reading!

\section{References}

Kasper, A.: Spontaneous cracking of thermally toughened safety glass. Part one: properties of nickel sulphide inclusions. Glass Struct. Eng. 4, 279-313 (2019a). https://doi.org/10. 1007/s40940-018-0083-8

Kasper, A.: Spontaneous cracking of thermally toughened safety glass part three: statistic evaluation of field breakage records and consequences for residual breakage probability. Glass Struct. Eng. 4, 345-376 (2019b). https://doi.org/10.1007/ s40940-018-00093-z

Kasper, A., Rubbert, F.: Spontaneous cracking of thermally toughened safety glass. Part four: a case study of isothermal breakages in a building, and conclusions thereof for the heat soak test. Glass Struct. Eng. (2020). https://doi.org/10. 1007/s40940-020-00118-6

Kasper, A., Pyeonglae, N., Yuan, Z.: Spontaneous cracking of thermally toughened safety glass Part two: nickel sulphide inclusions identified in annealed glass. Glass Struct. Eng. 4, 315-343 (2019). https://doi.org/10.1007/ s40940-018-00092-0

Publisher's Note Springer Nature remains neutral with regard to jurisdictional claims in published maps and institutional affiliations. 